\title{
Employment Challenges among Persons with Disabilities in Malaysia
}

\author{
Abdul Razak Abd Manaf, Siti Zubaidah Othman, Mohd Faizal Mohd Isa, Wan \\ Shakizah Mohd Mohd Noor \& Norizan Azizan
}

To Link this Article: http://dx.doi.org/10.6007/IJARBSS/v9-i10/6469

DOI: 10.6007/IJARBSS/v9-i10/6469

Received: 15 September 2019, Revised: 01 Oct 2019, Accepted: 15 Oct 2019

Published Online: 31 Oct 2019

In-Text Citation: (Manaf, Othman, Isa, Noor, \& Azizan, 2019)

To Cite this Article: Manaf, A. R. A., Othman, S. Z., Isa, M. F. M., Noor, W. S. M. M., \& Azizan, N. (2019). Employment Challenges among Persons with Disabilities in Malaysia. International Journal of Academic Research in Business and Social Sciences, 9(10), 139-148.

Copyright: (C) 2019 The Author(s)

Published by Human Resource Management Academic Research Society (www.hrmars.com)

This article is published under the Creative Commons Attribution (CC BY 4.0) license. Anyone may reproduce, distribute, translate and create derivative works of this article (for both commercial and non-commercial purposes), subject to full attribution to the original publication and authors. The full terms of this license may be seen at: $\underline{\text { http://creativecommons.org/licences/by/4.0/legalcode }}$

\section{Vol. 9, No. 10, 2019, Pg. 139 - 148}




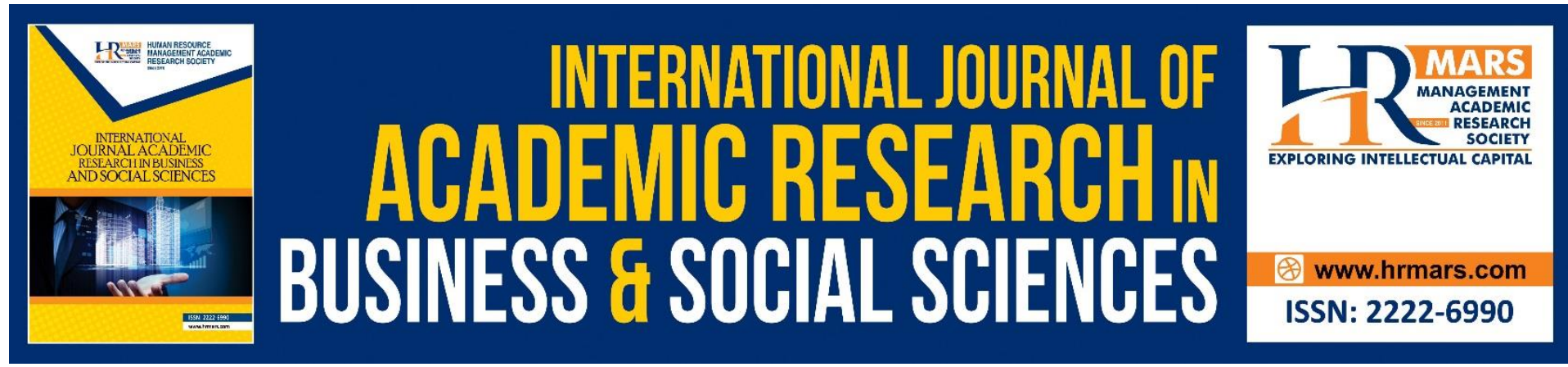

\title{
Employment Challenges among Persons with Disabilities in Malaysia
}

\author{
Abdul Razak Abd Manaf', Siti Zubaidah Othman², Mohd Faizal \\ Mohd Isa ${ }^{3}$, Wan Shakizah Mohd Mohd Noor ${ }^{4}$ \& Norizan Azizan ${ }^{5}$ \\ ${ }^{1}$ School of Applied Psychology, Social Work, and Policy, 2,3,4,5 School of Business Management \\ Universiti Utara Malaysia, 06010 Sintok Kedah, Malaysia
}

\begin{abstract}
Job participation among the disabled in Malaysia remains a complex issue. Despite the initiative and efforts being undertaken by various parties, this widely debated topic yet to be solved amicably. With the emergence of information and communication technology, the field of employment for persons with disabilities should have changed and created a new horizon for the disabled where they can work from home. But, the number of disabled employed by public or private organizations remained small. Therefore, the main objective of this study is to explore employment issues among Persons with Disabilities (PWDs) in Malaysia. To uncover these issues, input from 225 employed PWDs themselves were solicited through an on-site semi-structured interview. The results showed that among the crucial issues surrounding employability of PWDs in the workforce were due to negative perceptions from employers and peers, accessibility issues, lack of training, lack of support from family and personal attributes of PWDs themselves. Based on the findings of the study, several suggestions and recommendations were put forward to increase participation of PWDs in the workforce.
\end{abstract}

Keywords: Persons with Disabilities, Employment, Employability, Challenges, Malaysia

\section{Introduction}

Though many companies acknowledge that persons with disabilities are productive, reliable, hardworking and loyal, the reality shows that PWDs are not getting equal employment opportunities. Based on the statistic given by the human resource management information system database, until May 2015 only 2,985 PWDs are working in public sector (Statistik Pekerjaan dan Perburuhan Kementerian Sumber Manusia, 2015). Table 1 showed the breakdowns of PWDs working in the public sector by category of disabilities: 1,232 represent PWDs with physical disabilities, followed by 893 multiple disabilities, 558 visual impairment, 254 hearing impairment, 31 speech impairment, 12 mental, and 5 learning disabilities. Even though the number might be increasing since then, still it is not convincing or encouraging.

Table 1 
INTERNATIONAL JOURNAL OF ACADEMIC RESEARCH IN BUSINESS AND SOCIAL SCIENCES

Vol. 9, No. 10, October, 2019, E-ISSN: 2222-6990 @ 2019 HRMARS

PWDs working in the public sector by category of disabilities

\begin{tabular}{lcc}
\hline Category of Disabilities & Frequency & Percentage (\%) \\
\hline Physical disabilities & 1,232 & 41.27 \\
Multiple disabilities & 893 & 29.92 \\
Visual impairment & 558 & 18.69 \\
Hearing disabilities & 254 & 8.51 \\
Speech impairment & 31 & 1.04 \\
Mental & 6 & 0.40 \\
Learning disabilities & 5 & 0.17 \\
\hline Total & $\mathbf{2 , 9 8 5}$ & $\mathbf{1 0 0 . 0 0}$ \\
\hline
\end{tabular}

Source: Statistik Pekerjaan dan Perburuhan Kementerian Sumber Manusia 2015

In Malaysia, various initiatives have been carried out to promote the concept of independent PWDs and increase their opportunities for appropriate employment. For instance, the Ministry of Women, Family and Community Development (MWFCD) through its agency, the Department of Social Welfare (DSW), endeavors to improve the well-being of PWDs, including issues on employment and education. The long term mission of the Ministry with regards to PWDs is based "on the concept of equality of rights and opportunities for PWD to participate fully in society. This policy also emphasizes on human rights values such as integrity, honour and independence that will enable them to live independently" as reflected in the National Policy and Action Plan for PWDs.

(http://www.jkm.gov.my/content.php?pagename=dasar_orang_kurang_upaya\&lang).

The opportunities for participation of PWDs in the workforce are also stressed in Section 29 PWDs Act 2008, which stated that PWDs shall have the right to access to employment on equal basis with persons without disabilities. Among the initiatives taken include:

i. vocational and skills trainings at Pusat Latihan Perindustrian dan Pemulihan (PLPP) Bangi;

ii. employment opportunities for PWDs who are not able to compete in the current labour market at Bengkel Terlindung (Bengkel Daya, Klang, Selangor and Bengkel Daya, Sg. Petani, Kedah);

iii. $\quad$ recuperative programs at Pusat Pemulihan Dalam Komuniti (PDK);

iv. providing allowances - Elaun Pekerja Cacat (EPC) to employ PWDs with a monthly salary of RM1200 and below; and

v. introducing new initiatives for the development and wellbeing of PWDs such as the Job Coach, Disability Equality Training and Independent Living Programs

Apart from MWFCD, Ministry of Human Resources also plays a role in ensuring equal opportunities in employment for PWDs. Programs such as Return to Work and job carnival for PWDs organized by Social Security Organization (SOCSO) and supported employment by Labor Department, Ministry of Human Resources are some initiatives taken by this ministry to increase the participation of PWDs in the workforce. In addition, the SOCSO Rehabilitation Center Malacca is also established by the Ministry of Human Resource as a way to restore lost 
skills due to accidents and to improve their ability to work and be independent. Trainees are SOCSO contributors who become disabled due to accidents whilst on the job.

Given that PWDs should be equipped with good education, Ministry of Higher Education has played a proactive role in fulfilling this vision. For example, through community college and polytechnic, various courses that suit PWDs' capabilities are offered to enhance employability skills. The Ministry of Health also plays a role by providing many health assistance programs for PWDs. These include public health approach prevention such as Care of Children with Special Needs: Plan of Action; Community Mental Health and Psychosocial Rehabilitation 1998, Prevention and Control of Blindness 2000, Prevention and Management of Deafness and Hearing Impairment 2003; Sexual and Reproductive Health for Children and Adolescent with Disabilities 2004 and Strengthening of Rehabilitation Services at the Health Clinic 2004. These programs are implemented through the Health Care for Persons with Disabilities Program and Plan Action 1996 - 2010 and Health Care for PWD 2011 - 2020. The Public Service Department (PSD) has also introduced the implementation of $1 \%$ employment opportunities policy in the public sector for PWDs as stated in Service Circular No. 2/2008. This circular provided the outline for employing at least $1 \%$ PWDs in the public sector.

Despite of various initiatives and mandates imposed by the Malaysian government, the impact on improving the livelihood of PWDs in Malaysia, especially one that relates to employment, is still questionable. Even with the implementation of these policies and programs, the participation of PWDs in the workforce remains relatively low. In the past, many studies have been conducted to examine the reasons for low participation of PWDs in the labor market and found that factors such as barriers in the environment (access to education and transportation), barriers in the employment process (skill deficits, disability stigma and cost of accommodations) and attitudes of employers toward hiring PWDs contributed to some of the issues (Bruyere, 2000; Garske \& Stewart, 1999; Marrone \& Golowka, 1999; Khoo, Tiun \& Lee, 2013; Pratt, Gill, Barret \& Roberts; 1999; Roessler, 2002; Stacher \& Hendren, 1992; Tiun \& Khoo, 2013; Wright \& Multon, 1995).

However, having an understanding on the barriers per se is not sufficient to promote disabled to join the employment. What is most important is how to transform disability to ability. By understanding the employability criteria for disabled, barriers between the employers and the disabled can be broken down and proper development program can be conducted as a way to promote employability and employment of PWDs. Therefore, this paper shared the real issues attributing to the low participation of PWDs in the workforce with some suggestions that could be taken to enhance their employability.

\section{Literature Review}

As argued by Walsh, Lydon and Healy (2014), employment enables one to be part of the community as it helps people to develop social skills that are required in daily activities such as communication skills, negotiation, problem solving skills, interpersonal skills, and decision making skills. Furthermore, employment is also seen as a way to improve socio-economic status (Lamichhane, 2012). Salary received allows employees to allocate for saving and at the same time increase their purchasing power (Bualar, 2014; Cocks, Thoresen, \& Lee, 2013). The 
purchasing power permits employee to buy assets. The assets will secure and improve the socio-economic status of PWDs.

However, issues of employment among PWDs remain unresolved although it has been long discussed (Ang \& Ramayah, 2015; Cocks, Thoresen \& Lee, 2013; Duff, Ferguson \& Gilmore, 2007; Jayasooria, Krishnan \& Ooi, 1997; Jayasooria \& Ooi, 1994; Lengnick-Hall, Gaunt Kulkarni, 2008). The participation of PWDs in the labor market is limited and mostly excluded (Gartrell, 2010; Hoque, Bacon \& Parr, 2014; Stevens, 2002). The exclusion of PWDs from employment opportunities is linked to the social organization of the labor market, not because of individual impairment. Ramakrishnan (2007) suggested that organizational commitment to employment of the disabled, attitude towards disabled people, and organizational policies on PWDs are critical factors in the employment opportunities for the disabled. Barriers such as access to education, information, transport, built environment, as well as cultural and media representations have been claimed to be among the reasons for low participation of PWDs in joining the workforce.

Tiun and Khoo (2013) and Khoo, et al., (2013) found that most employers in general were unfamiliar with and insensitive to the needs of their employees with disability. The physical infrastructures in the workplace were not disability-friendly which hindered the movements of employees with disability. The findings further showed that compared to government agencies, private sector was more concerned about meeting the needs of PWDs. Khoo et al., (2013) highlighted two critical factors, namely unconducive environment and workplace barriers, as the obstacles which impeded PWDs from entering and progressing in the workplace.

Barnes (2005) argued that specific policy intervention in the field of employment alone will not be enough to curb this problem unless those barriers are lifted. Hamad (2007) believed that full access to educational opportunities to learn needed skills is the first step in achieving social integration and ensuring equal employment opportunities. Norani, Khalid and Nor Aishah (2001) discovered that special needs individuals have many hidden potentials and resources, and thus, they should be given job opportunities and training in order to fully integrate themselves in the society at large.

Employer perceptions toward the disabled workforce have also been cited as a significant barrier to the employment of PWDs. Research showed that though applicants with disabilities are evaluated more positively during hiring process, they are still less likely to be hired than candidates without disabilities (Tagalakis, Amsel \& Fichten, 1988). In particular, employers were concerned about productivity, demand for supervision, and promotability of workers with disabilities, as well as the cost of accommodating their needs (Johnson, Greenwood \& Schriner, 1988). In addition, unwillingness of the organization to provide accommodations that suite their needs, negative perception by the organization, inappropriate jobs, and limited mobility access are among causes for PWDs to be marginalized in the labor market (Berthoud, 2008; Coffey, Coufopoulos, \& Kinghorn, 2014; Hoque et al., 2014; Ta \& Leng, 2013). 
Training is another concerning issue related to PWDs. The main goal of training is to increase knowledge, skills, and ability in performing jobs. Yet, persons with disabilities do not receive the same training opportunity compared to other employees. Training appears to play significant roles in helping disabled persons to be employed (Anizam, Manisah \& Amla, 2014). However, their participation in training activity is limited compared to non-disabled persons (Pagán, 2015). Poor facilities, out-dated syllabus, and lack of skills demonstrated by the trainer are among the factors that contribute to this problem (Malle, Pirttimaa, Saloviita, 2015). As these issues are not addressed by the respective authorities, organization or training centre, the problem will remain. Thus, disabled persons will not be able to develop or enhance their skills (Pagán, 2015), and this decreases their chances of being employed.

Finally, the role of organization in providing training to their disabled employee is another issue concerning training for disabled persons (Kulkarni \& Kote, 2014). Organizations are unsure whether their disabled employees should receive the same training opportunity as non-disabled employees or the training is a part of social responsibility. As a consequence, PWDs have limitations to further training throughout their service tenure in organization (Kulkarni \& Kote, 2014; Pagán, 2015). The negative effects of this unhealthy situation resulted in segregation of duties between disabled and non-disabled employees and hindrance from full participation for disabled employees in organization (Malle, Pirttimaa \& Saloviita, 2015; Polidano \& Mavromaras, 2011).

\section{Methodology}

\section{Research design}

In this study, an on-site semi-structured interviews were utilized as the data collection method to uncover participants' perspectives on the employment issues. Respondents were asked to elaborate on their experiences and perceptions in relations to employment issues. Thus, interviews allowed for flexibility and openness. Questions were exploratory and discovery-oriented (Strauss \& Corbin, 1998); thus, allowing the participants to express issues of employment within their own frame of references. The one-to-one interview lasted for an average of one hour.

All responses were transcribed and scrutinized very closely. Each item was coded using open coding, and allowed categories and themes to develop and emerge without selective attention to points of particular interest (Coffey \& Atkinson, 1996). As the coding progressed, additional categories were identified and added to the coding guide, using the same process. Upon completion of the coding activity, the researchers proceeded to the next level of analysis, whilst comparing and contrasting the categories to discover the relationship between them. The aim of this second level of analysis was to collapse the categories into themes and sub-themes by locating patterns that were consistent in the data set. Once the codes and categories were derived from the text, the patterns were then compared across interview transcripts. This started with open coding, then clustering the codes into families of concepts or categories and finally capturing emergent themes from the clusters or codes. This step took place to capture the concepts linking the thematic material in order to make an attempt of the final thematic conceptualization analysis. The themes were then arranged in a hierarchical manner into major and minor themes. 


\section{Participants}

A total of 225 employed PWDs (143 male and 82 female) from around Peninsular Malaysia were interviewed. Out of 225, 161 of them are still single, 56 are married and 8 are divorced. It is noted that 125 of the employed PWDs are still living with their parents. The findings also showed that 138 employed PWDs live in the urban area. Of the 225 employed PWDs, 174 of them work in the private sector. Majority of them (115 participants) worked in the central region. A total of 114 participants are employed as full time employees (34 participants in the government sector; 80 participants in the private sector). Majority of the employed PWDs (206 participants) worked in the service industries. In terms of monthly income, majority of them (135 participants) received less than RM1000.

\section{Results and Discussions}

This section discussed the responses gathered from 225 employed PWDs regarding the challenges faced at the workplace. However, only 134 or $60.0 \%$ of the 225 respondents shared their opinions. Table 2 summarizes the respondents' responses in the percentage form.

As shown in Table 2, potential challenges PWDs faced at the workplace include negative perceptions from employers (24.63\%), lack of training to perform their jobs (23.88\%), limited workplace accessibilities (22.39\%), negative perceptions from peers $(21.64 \%)$, lack of family support (14.18\%), and financial problems (18.66\%). In addition, poor communication and lack of working experience were also cited as challenges faced by PWDs at the workplace.

The top four challenges could be categorized as unhealthy working climate in the organization. Unhealthy working climate could affect the harmony between the system and people in the organization. If this situation persisted, it would create more negative behaviors among workers in the organization. Relevant agencies and organizations should also continuously capitalize their resources to meet the challenges faced by the employed PWDs and their organizations. In fact, support system from the community ought to be further strengthened in order for PWDs to be fully integrated in the workforce.

Table 2

Summary of responses regarding challenges at the workplace $(n=134)$

\begin{tabular}{clcc}
\hline Number & \multicolumn{1}{c}{ Challenges at the workplace } & $\begin{array}{c}\text { Number of } \\
\text { responses }\end{array}$ & Percentage \\
\hline 1. & Negative perception from employers & 33 & 24.63 \\
2. & Lack of training to help them perform jobs & 32 & 23.88 \\
3. & Limited accessibility to workplace & 30 & 22.39 \\
4. & Negative perception from peer & 29 & 21.64 \\
5. & Financial problem & 25 & 18.66 \\
6. & Lack of support from family & 19 & 14.18 \\
7. & Poor communication & 9 & 6.72 \\
8. & Lack of work experience & 8 & 5.97 \\
& & & \\
\hline
\end{tabular}




\section{Conclusions and Recommendations}

Based on the findings, the following are some of the recommendations to increase the participation of PWDs in employment. The findings suggested that there are a need for enhancement of employment-supported program by providing on-going support for both PWDs and employers such as improving the function of Jobs Malaysia and other development programs. At the same time, job coach also need to be empowered by revising and improvising job coach roles and responsibilities; giving more in-house training and development for job coach in organization; increasing the number of job-coach across ministries; providing more attractive incentives and benefits for organization participating in job-coach program and providing with resource guide for employers in recruiting, hiring, retaining and promoting PWDs.

\section{Acknowledgement}

We would like to express our heartfelt gratitude and deepest appreciation to Social Institute of Malaysia for awarding the research grant to undertake this study.

\section{Corresponding Author}

Abdul Razak Abd Manaf

Ph.D, School of Applied Psychology, Social Work, and Policy

Universiti Utara Malaysia, 06010, Sintok Kedah

Malaysia

Email: a.razak@uum.edu.my

\section{References}

Ang, M. C. H., \& Ramayah, T. H. A. (2015). Equality, diversity and inclusion. International Journal, 34(3), 186-200.

Yusof, A. M., Ali, M. M., \& Salleh, A. M. (2014). Employability of vocational school leavers with disabilities. Procedia - Social and Behavioral Sciences, 112(2014),1064-1069.

Barnes, C., \& Mercer, G. (2005). Disability, work and welfare: Challenging the social exclusion of disabled people. Work, employment and society, 19(3), 527-544.

Berthoud, R. (2008). Disability employment penalties in Britain. Work, Employment \& Society, 22(1), 129-148. doi:10.1177/0950017007087420.

Bruyere, S. M. (2000). Statistics about people with disabilities and employment. Retrieved from http://www.dol.gov/odep/pubs/ek01/stats.htm.

Bualar, T. (2014). Barriers to employment: Voices of physically disabled rural women in Thailand. Community, Work \& Family, 17(2), 181-199. doi:10.1080/13668803.2013.806125

Cocks, E., Thoresen, S. H., \& Lee, E. A. L. (2013). Employment and related economic outcomes for Australian apprenticeship and traineeship graduates with disabilities: Baseline findings from a national three-year longitudinal study. Journal of Vocational Rehabilitation, 39(3), 205-217. doi:10.3233/JVR-130654.

Coffey, A., \& Atkinson, P. (1996). Making sense of qualitative data: Complementary research strategies. Thousand Oak, CA: Sage Publications.

Coffey, M., Coufopoulos, A., \& Kinghorn, K. (2014). Barriers to employment for visually impaired women. International Journal of Workplace Health Management, 7(3), 171185. 
Duff, A., Ferguson, J., \& Gilmore, K. (2007). Issues concerning the employment and employability of disabled people in UK accounting firms: An analysis of the views of human resource managers as employment gatekeepers. British Accounting Review, 39, 15-38. doi:10.1016/j.bar.2006.08.003.

Gartrell, A. (2010). A frog in a well: The exclusion of disabled people from work in Cambodia. Disability \& Society, 25(3), 289-301. doi:10.1080/09687591003701207.

Garske, G. G., \& Stewart, J. R. (1999). Stigmatic and mythical thinking: Barriers to vocational rehabilitation services for persons with severe mental illness. Journal of Rehabilitation, 65(4), 4-8.

Hamad, S. (2007). For equal employment opportunities, report on the consultation regarding the national strategy for labor market integration and maintenance of handicapped persons, Minister of Employment and Social Solidarity.

Hoque, K., Bacon, N., \& Parr, D. (2014). Employer disability practice in Britain: Assessing the impact of the positive about disabled people two ticks symbol. Work, Employment \& Society, 28(3), 430-451. doi:10.1177/0950017012472757

Jayasooria, D., Krishnan, B., \& Ooi, G. (1997). Disabled people in a newly industrialising economy: Opportunities and challenges in Malaysia. Disability \& Society, 12, 455-463. doi:10.1080/09687599727281.

Johnson, V. A., Greenwood, R., \& Schriner, K. F. (1988). Work performance and work personality: Employer concerns about workers with disabilities. Rehabilitation Counseling Bulletin, 32, 50-57.

Khoo, S. L., Tiun, L. T., \& Lee, L. W. (2013). Unseen challenges, unheard voices, unspoken desires: Experiences of employment by Malaysians with physical disabilities. Kajian Malaysia, 31(1), 37-55.

Kulkarni, M., \& Kote, J. (2014). Increasing employment of people with disabilities: The role and views of disability training and placement agencies. Employee Responsibilities and Rights Journal, 26(3), 177-193. doi:10.1007/s10672-013-9216-z.

Lamichhane, K. (2012). Employment situation and life changes for people with disabilities: Evidence from Nepal. Disability \& Society, 27(4), 471-485. doi:10.1080/09687599.2012.659462.

Lengnick-Hall, M. L., Gaunt, P. M., \& Kulkarni, M. (2008). Overlooked and underutilized: People with disabilities are an untapped human resource. Human Resource Management, 47(2), 255-273. doi:10.1002/hrm.

Malle, Y. A., Pirttimaa, R., \& Saloviita, T. (2015). Inclusion of students with disabilities in formal vocational education programs in Ethopia. International Journal of Special Education, 30(2), 1-10.

Marrone, J., \& Golowka, E. (1999). If work makes people sick, what do unemployment, poverty and social isolation cause? Psychiatric Rehabilitation Journal, 23(2), 187-193.

Salleh, N. M., Abdullah, K., \& Buang, N. A. (2001). Job opportunities for special needs population in Malaysia. Jurnal Pendidikan, 27, 77-85.

Pagán, R. (2015). Determinants of participation in further training among workers with disabilities. Disability and Rehabilitation, 37(11), 1009-1016.

doi:10.3109/09638288.2014.948140. 
Policy and action plan for the disabled (OKU) 2007. Retrieved from http://www.jkm.gov.my/content.php?pagename=dasar_dan_pelan_tindakan_oku\&l ang=en.

Pratt, C. W., Gill, K. J., Barret, N. M., \& Roberts, M. M. (1999). Psychiatric rehabilitation. San Diego, CA: Academic Press.

Ramakrishnan, P. (2007). Critical factors influencing employment of disabled persons in Malaysia. Online Thesis. University of South Australia. http://arrow.unisa.edu.au:8081/1959.8/78821.

Roessler, R. (2002). Improving job tenure outcomes for people with disabilities: The $3 \mathrm{M}$ model. Rehabilitation Counseling Bulletin, 45(4), 207-212.

Stacher, J., \& Hendren, G. R. (1992). Employer agreement with the Americans with Disabilities Act of 1990: Implications for rehabilitation counselling. Journal of Rehabilitation, 58(3), 13-17.

Statistik Pekerjaan dan Perburuhan Kementerian Sumber Manusia. (2015). Pendaftaran orang kurang Upaya (OKU) mengikut etnik \& kategori ketidakupayaan. Retrieved from http://www.mohr.gov.my.

Stevens, G. R. (2002). Employers' perceptions and practice in the employability of disabled people: A survey of companies in south east UK. Disability \& Society, 17(7), 779-796. doi:10.1080/0968759022000039073.

Strauss, A., \& Corbin, J. (1998). Basic of qualitative research: Techniques and procedures for developing grounde theory ( $2^{\text {nd }}$ ed.). Thousand Oaks, CA: Sage Publication.

Ta, T. L., \& Leng, K. S. (2013). Challenges faced by Malaysians with disabilities in the world of employment, 24(1), 6-21. doi:10.5463/DCID.v24i1.142.

Tagalakis, V., Amsel, R., \& Fichten, C.S. (1988). Job interviewing strategies for people with a visible disability. Journal of Applied Social Psychology, 18, 520-532.

Tiun, L. T., \& Khoo, S. L. (2013). Challenges faced by Malaysians with disabilities in the world of employment. Disability, CBR \& Inclusive Development, 24(1), 6-21.

Walsh, L., Lydon, S., \& Healy, O. (2014). Employment and vocational skills among individuals with autism spectrum disorder: Predictors, impact, and interventions. Review Journal of Autism and Developmental Disorders, 1, 266-275. doi:10.1007/s40489-014-00247.

Wright, G. E., \& Multon, K. D. (1995). Employers' perceptions of nonverbal communication in job interviews for persons with physical disabilities. Journal of Vocational Behavior, 47, 214-227. 